\title{
First Report of Amaranthus palmeri S. Wats. in Cotton, Maize and Sorghum in Greece and Problems with Its Management
}

\author{
Panagiotis Kanatas ${ }^{1, *(\mathbb{D})}$, Alexandros Tataridas ${ }^{2}\left(\mathbb{D}\right.$, Vyronas Dellaportas ${ }^{2}$ and Ilias Travlos $^{2}$ (D) \\ 1 Department of Crop Science, University of Patras, P.D. 407/80, 30200 Mesolonghi, Greece \\ 2 Laboratory of Agronomy, Department of Crop Science, Agricultural University of Athens, 75 Iera Odos Str, \\ 11855 Athens, Greece; a.tataridas@gmail.com (A.T.); delaportas23@gmail.com (V.D.); travlos@aua.gr (I.T.) \\ * Correspondence: pakanatas@gmail.com; Tel.: +30-6977-568-815
}

check for updates

Citation: Kanatas, P.; Tataridas, A.; Dellaportas, V.; Travlos, I. First Report of Amaranthus palmeri S. Wats. in Cotton, Maize and Sorghum in Greece and Problems with Its Management. Agronomy 2021, 11, 1721. https://doi.org/10.3390/ agronomy11091721

Academic Editor: Mark P. Widrlechner

Received: 12 August 2021

Accepted: 26 August 2021

Published: 28 August 2021

Publisher's Note: MDPI stays neutral with regard to jurisdictional claims in published maps and institutional affiliations.

Copyright: (C) 2021 by the authors Licensee MDPI, Basel, Switzerland. This article is an open access article distributed under the terms and conditions of the Creative Commons Attribution (CC BY) license (https:/ / creativecommons.org/licenses/by/ $4.0 /)$.

\begin{abstract}
Amaranthus palmeri S. Wats., or commonly Palmer amaranth, is an invasive plant species that has invaded many countries worldwide and causes significant yield losses to annual spring crops. Palmer amaranth biotypes were detected in maize and sorghum fields in Western Greece and cotton fields in Central Greece in 2020. The infestations were recorded both inside the crops and in the margins of the fields, indicating that Palmer amaranth could be characterized as an invasive weed for these regions and, thus, must be urgently managed. Four biotypes were screened for resistance to 2,4-D and nicosulfuron by using NDVI, canopy cover, photochemical efficiency, plant height and fresh weight values. All biotypes showed resistance to nicosulfuron. Resistance cases to important herbicides (i.e., ALS and synthetic auxins) in spring crops, such as maize and cotton, indicate that management could become even more challenging if farmers do not adopt integrated strategies and tools to manage this weed. The eradication of Palmer amaranth plants is imperative, since it has yet to be dispersed in several agricultural areas of Greece. Palmer amaranth is recommended to be enlisted as quarantine pest for regulation in Greece.
\end{abstract}

Keywords: Palmer amaranth; maize; cotton; sorghum; invasive; herbicide resistance; Fv /Fm

\section{Introduction}

Palmer amaranth (Amaranthus palmeri S. Wats.) belongs to the Amaranthaceae family and is a C4 dioicous plant species. It is mainly wind-pollinated and demonstrates high fecundity with up to 600,000 seeds per plant being recorded [1]. Palmer amaranth can be easily identified in the flowering stage. The female plants develop a long cylindrical inflorescence (up to $60 \mathrm{~cm}$ ) with prickly surface from the central stem, while the male inflorescence is smoother. Palmer amaranth has rapid growth rate that leads in high biomass accumulation and thus, results in more intense competition with crops for nutrients, water and light irradiation. The identification of Palmer amaranth is crucial even from the first vegetative growth stages. Redroot pigweed (Amaranthus retroflexus L.) is another species of genus Amaranthus that is common in Greece and looks similar to Palmer amaranth in the first vegetative growth stages, hence making the identification a major challenge. Both species present a high variability in the fields. However, the main difference is the inflorescence and the hair on the leaves. The biology and ecology of A. palmeri have been reviewed and are thoroughly presented in the pest risk analysis for Palmer amaranth, generated by EPPO, and the review of Ward et al. (2013) [1].

There are currently 69 confirmed herbicide-resistance cases globally of Palmer amaranth with single or multiple mechanisms of action. The majority has been recorded in soybean, cotton and maize, and less in sorghum, squash and orchards [2,3]. Some herbicides, though, are extensively used by farmers in Greece in various crops for the preemergence and post-emergence weed management (Table 1). Sulfonylureas and synthetic auxin resistance is expected to pose a major threat for the sustainability of agricultural production in spring arable crops, since the post-emergence weed management in maize 
and cotton relies strongly on those. Pendimethalin and S-metolachlor are two efficient herbicides that are widely used in Greece for pre-emergence weed control. Should Palmer amaranth evolve resistance to these active ingredients, the weed will become dominant in spring crop fields and might alter the weed flora. It has to be noted that the pollen of Palmer amaranth can be transferred through wind in long distances (over $300 \mathrm{~m}$ ), bringing herbicide resistance traits in new biotypes, as the weed is an obligate outcrosser. Herbicide resistance cases have been already reported in Spain [4]. Recently, the weed has been detected in soybean fields in Italy, where, notably, herbicide resistance is already present [5].

Table 1. Herbicides' active ingredients to which Palmer amaranth has evolved resistance.

\begin{tabular}{ccc}
\hline Active Ingredient & Site of Action & Classification HRAC Group \\
\hline $\begin{array}{c}\text { Foramsulfuron, iodosulfuron-methyl, } \\
\text { mesosulfuron-methyl, rimsulfuron, } \\
\text { trifloxysulfuron, nicosulfuron, } \\
\text { halosulfuron-methyl, pyrithiobac-sodium }\end{array}$ & Inhibition of acetolactate synthase (ALS) & B \\
\hline Pendimethalin & Microtubule assembly inhibition & K1 \\
\hline S-metolachlor & Inhibition of cell division & K3 \\
\hline Mesotrione & $\begin{array}{c}\text { Inhibition of } \\
\text { (4-HPPD) }\end{array}$ & F2 \\
\hline Glyphosate & Inhibition of EPSPS synthase & G \\
\hline 2,4-D, dicamba & Synthetic auxins & O
\end{tabular}

It has been suggested that the management of Palmer amaranth requires the integration of several methods, such as the combination of herbicides with different mechanisms of action [6]; the active ingredients rotation; the use of cover crops, such as rye [7]; the increase of crop competitiveness through density sowing and row-spacing adjustments; and the optimized soil tillage in order to prevent Palmer amaranth seeds from soil seedbank come in the soil surface.

The aim of this research was to screen Greek Palmer amaranth biotypes for putative resistance to a synthetic auxin (2,4-D) and an ALS inhibitor (nicosulfuron). For this purpose, assessment of the response of the weed to herbicides was conducted through remote sensing and agronomic traits. This research also aims to reveal the significance of a smart application that measures canopy cover for rapid and robust evaluation of herbicide efficacy.

\section{Materials and Methods}

\subsection{Weed Detection and First Surveys}

Field monitoring was conducted in June and July 2020 in maize and sorghum fields in Vonitsa region, Western Greece, and cotton fields in Domokos region, Central Greece (Table 2), to identify Palmer amaranth infestations after reports from farmers on failed herbicide applications against an unknown weed. A total number of more than 20 fields was randomly surveyed. Each surveyed field was walked through by the two diagonals and a representative sample of seeds was collected. The surveyed maize and sorghum fields were under monoculture at least during the last 10 years. Cotton crop was also a monoculture for the specific fields in Central Greece. In both regions, farmers apply post-emergence herbicides in spring (ALS and 2,4-D, in rotation and in tank mixtures) to manage weeds. Moreover, some pre-emergence herbicides are also applied in cotton. Tillage is exclusively conventional, with yearly deep ploughing, disc harrowing and the use of cultivator in spring prior to sowing. 
Table 2. Palmer amaranth biotypes location in Greece.

\begin{tabular}{cccc}
\hline Biotype & Region & Crop & Location Coordinates \\
\hline Cotton-S & Central Greece & cotton & $39^{\circ} 21^{\prime} 42^{\prime \prime} \mathrm{N}, 22^{\circ} 28^{\prime} 79^{\prime \prime} \mathrm{E}$ \\
Cotton-R1 & Central Greece & cotton & $39^{\circ} 22^{\prime} 83^{\prime \prime} \mathrm{N}, 22^{\circ} 28^{\prime} 22^{\prime \prime} \mathrm{E}$ \\
Cotton-R2 & Central Greece & cotton & $39^{\circ} 22^{\prime} 46^{\prime \prime} \mathrm{N}, 22^{\circ} 28^{\prime} 04^{\prime \prime} \mathrm{E}$ \\
Maize & Western Greece & maize & $38^{\circ} 52^{\prime} 12^{\prime \prime} \mathrm{N}, 20^{\circ} 51^{\prime} 51^{\prime \prime} \mathrm{E}$ \\
\hline
\end{tabular}

\subsection{Seed Collection and Plant Samples}

Palmer amaranth seeds and seedlings were collected from the inspected fields and transferred to the Laboratory of Agronomy of the Agricultural University of Athens, Greece, in June/July 2020 (latitude, $37^{\circ} 59^{\prime} 02^{\prime \prime} \mathrm{N}$; longitude, $23^{\circ} 42^{\prime} 09^{\prime \prime} \mathrm{E}$ ). The seeds were air-dried, threshed, placed in paper bags, stored at room temperature and sown. In total, 12 pots were used for each biotype. Plastic pots had 13-L capacity and were filled with a mix of herbicide-free soil from the experimental field of the Agricultural University of Athens and peat at the ratio of 1:1 $(\mathrm{v} / \mathrm{v})$. The soil of the experimental field is clay loam (CL) with $\mathrm{pH}$ value of 7.29 , whereas the contents of $\mathrm{CaCO}_{3}$ and organic matter were $15.99 \%$ and $2.37 \%$, respectively. All pots were placed outdoors (with mean temperature ranging between 24.3 and $39.1{ }^{\circ} \mathrm{C}$ and mean relative humidity lower than $45.4 \%$ ) and properly irrigated throughout the experimental run.

\subsection{Experimental Design}

The experiment was a factorial arrangement of biotype and herbicide treatment arranged in a completely randomized design. The three experimental treatments were applied in 4 pots (4 replications) for each biotype. Herbicide treatments included an untreated control, 2,4-D at a rate of $600 \mathrm{~g}$ a.e. ha ${ }^{-1}$ and nicosulfuron at a rate of $45 \mathrm{~g}$ a.i. ha ${ }^{-1}$. Herbicides were applied when the majority of the plants was at 4-8 leaves and at 8-12 cm height. All herbicide applications were carried out with a custom-built, compressed-air, low-pressure flat-fan nozzle experimental sprayer. Spraying was carried out at $0.2 \mathrm{MPa}$ pressure, and the spraying angle was $80^{\circ}$. The height between the conical nozzle and the soil level was $40 \mathrm{~cm}$ for all the experimental treatments. The spray head was set to move over the plants at $1.5 \mathrm{~km} \mathrm{~h}^{-1}$, and the apparatus was calibrated to deliver the equivalent of $200 \mathrm{~L} \mathrm{ha}^{-1}$. The spraying was conducted when the air temperature was $27^{\circ} \mathrm{C}$ and the humidity $20 \%$.

\subsection{Measurements}

The evaluation of the efficacy of 2,4-D and nicosulfuron against Palmer amaranth biotypes was conducted 21 days after treatment (DAT). Fresh weight and plant height were recorded from 4 individual plants per treatment after clipping of the above ground biomass. Survival rate was also recorded based on the number of living plants as a proportion of the total number of plants subjected to the herbicide. Remote sensing and smart applications were also used to identify the susceptibility of Palmer amaranth biotypes to specific herbicides and quantify the responses (Figure 1). A portable handheld crop sensor device GreenSeeker Handheld Crop Sensor was used (GreenSeeker Handheld Crop Sensor, Trimble Agriculture Division, Westminster, CO, USA) to record the Normalized Difference Vegetation Index (NDVI). NDVI is commonly used as an indicator of vegetation health based on the intensity of reflection of red and far red light [8]. It has to be noted that recently a novel method (quick test) based on NDVI was developed for the in-season rapid evaluation of herbicide efficacy and herbicide resistance detection [8]. Canopeo (Division of Agricultural Sciences and Natural Resources, the OSU App Center and Oklahoma State University, in Google Play) was also used as an application that allows to accurately determine the percent of green canopy cover, via downward-facing photos taken from the mobile devices in real time. It is an image-analysis tool that classifies all pixels in the image and the result of the analysis is a binary image, where white pixels correspond to the pixels that satisfied the selection criteria (green canopy) and black pixels correspond to the pixels 
that did not meet the selection criteria (not green canopy). Fractional green canopy cover ranges from 0 (no green canopy cover) to 1 (100\% green canopy cover). The pots were placed in the center of a $0.25 \mathrm{~m}^{2}$ quadrat with black background to compare the canopy cover after the herbicide applications between the treatments and the biotypes. Moreover, the efficacy of herbicides was measured according to the efficiency of Photosystem II by estimating the Fv/Fm (maximum photochemical efficiency of PSII or quantum yield) and using FluorPen FP 110 (PSI (Photon Systems Instruments) spol. s r.o., Drasov 470, 66424 Drasov, Czech Republic). FluorPen FP 110 is a portable, battery-powered fluorometer that enables quick measurement of chlorophyll fluorescence parameters in the field. It is equipped with a blue LED emitter $(455 \mathrm{~nm})$, optically filtered and precisely focused to deliver light intensities of up to $3000 \mu \mathrm{mol} \mathrm{m}{ }^{-2} \mathrm{~s}^{-1}$ to measured plant tissue. Palmer amaranth plants were covered with black plastic bags for $20 \mathrm{~min}$ to stop photochemistry, allowing the measurement of fluorescence in the presence of non-photochemical quenching alone. The measurement was conducted by using 4 leaves for each treatment and for every biotype.

\section{Canopy cover}

Fv/Fm

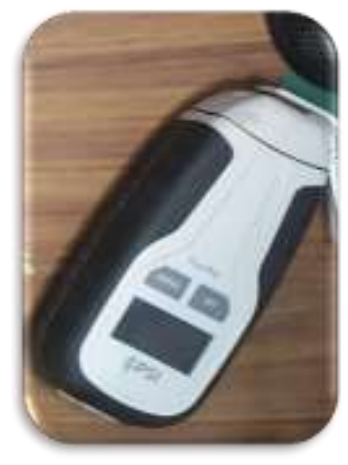

NDVI

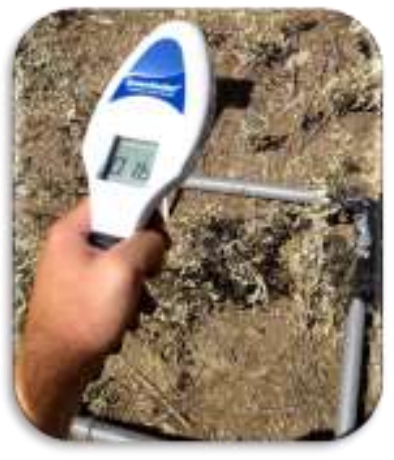

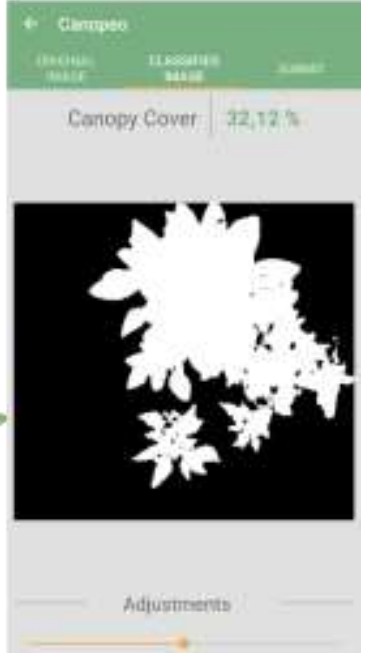

Figure 1. Use of handheld instruments and smart applications to measure Fv/Fm, NDVI and canopy cover.

\subsection{Statistical Analysis}

All the data were checked for normal distribution by using the Shapiro-Wilk test. The variance check was performed by using Levene's test for all the data. The data were subjected to analysis of variance (ANOVA), using STATGRAPHICS Centurion XVII Version statistical software (Statpoint Technologies Inc., The Plains, VA, USA). The differences between means were tested at the $\alpha=0.05$ significance level, using Fischer's least significant difference (LSD) test. Multiple analysis of variance (MANOVA) was conducted for the factors of biotype and treatment (both as fixed effect) and their interactions. Replication was considered a random effect. Multiple comparisons (post hoc tests) were performed to separate means among treatments. Regression analysis was conducted at the $\alpha=0.05$ significance level to correlate NDVI and Canopeo measurements, according to the following linear model:

$$
Y=A+B \times X
$$

where $Y$ refers to the values of NDVI, and $X$ represents the values of Canopeo app. 


\section{Results}

\subsection{Weed Detection}

Palmer amaranth plants were identified in multiple fields of both regions. The density was relatively low in Western Greece (3-6 plants per $\left.\mathrm{m}^{2}\right)$ and slightly higher in Central Greece (5-15 plants per $\mathrm{m}^{2}$ ). In particular, Palmer amaranth plants were identified in cotton fields (Figure 2A) in Central Greece and in maize and sorghum fields (Figure 2C) in Western Greece. Infestations were observed both in field margins and among the crops. The high density in field margins and non-agricultural areas could act as a reservoir for Palmer amaranth seed production and future seed dispersal and infestations.
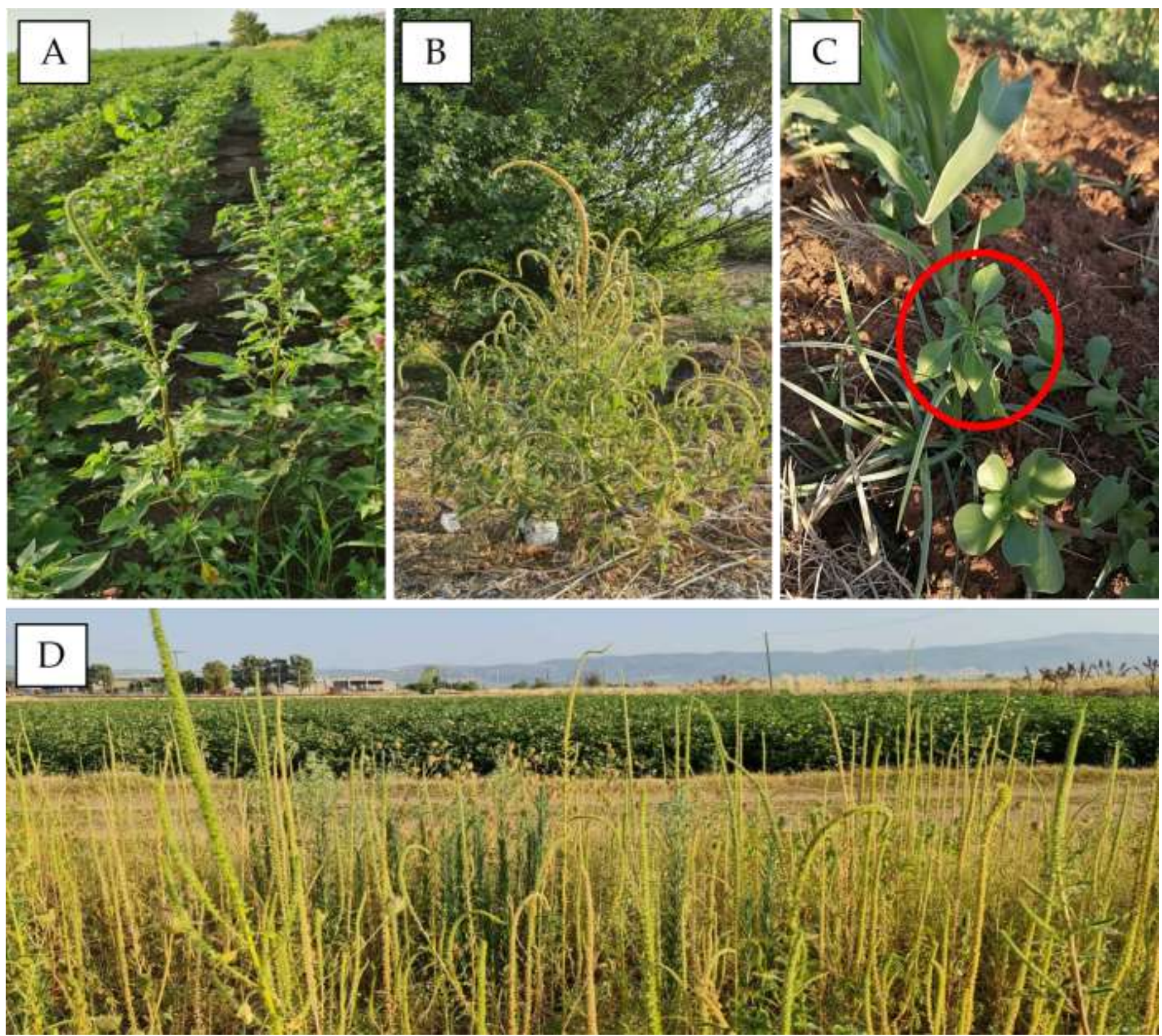

Figure 2. Palmer amaranth infestations in cotton (A), maize (C) and field margins (B,D).

\subsection{Management}

The effects of biotype $(\mathrm{B})$, treatment $(\mathrm{T})$, and their interaction $(\mathrm{B} \times \mathrm{T})$ on Palmer amaranth fresh weight were significant at $p<0.001$ level (Figure 3 ). The fresh weight of plants treated with $2,4-\mathrm{D}$ significantly varied between the biotypes $(p<0.05)$. The Cotton-S 
biotype was more susceptible to 2,4-D compared to the other biotypes from cotton fields in terms of fresh weight reduction. The Cotton-R2 biotype demonstrated the highest fresh weight among the treatments in the case of nicosulfuron, indicating that it was the most resistant biotype. The other biotypes demonstrated similar fresh weight values after nicosulfuron application (Figure 3(1)). In all biotypes, statistically significant differences were observed between control and 2,4-D treatments $(p<0.001)$. The biotype and the treatment had statistically significant effect $(p<0.005$ and $p<0.001$, respectively) on plant height, with their interaction $(\mathrm{B} \times \mathrm{T})$ being also significant $(p<0.005)$ (Figure 3(2)). Plants treated with 2,4-D resulted in lower plant height in comparison to untreated plants and those treated with nicosulfuron in all biotypes.

\section{घCotton-S घCotton-R1 a Cotton-R2 a Maize}
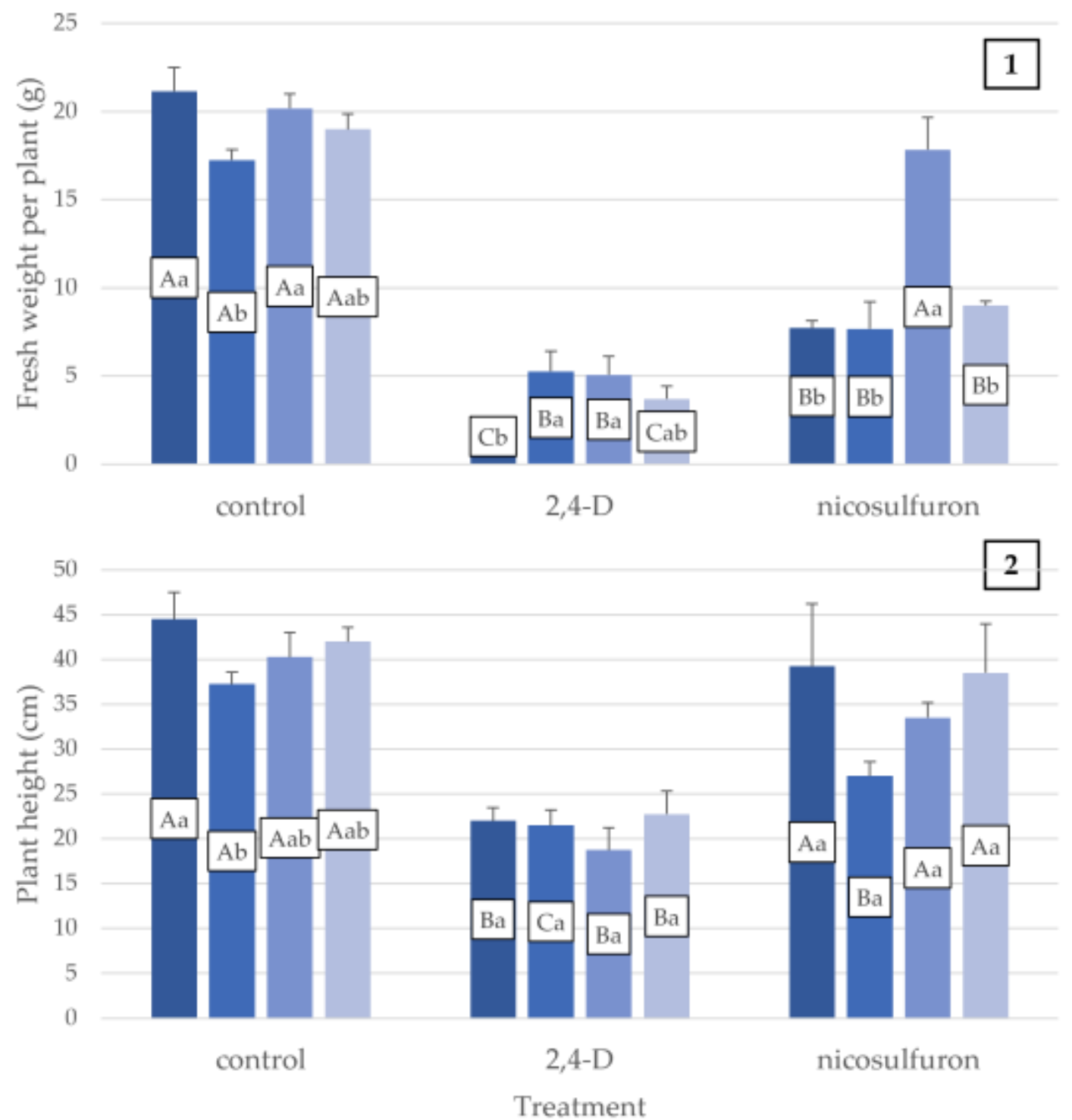

Figure 3. Fresh weight per plant (1) and plant height (2) at 21 DAT for the three A. palmeri biotypes from cotton and the one from maize. Vertical bars indicate standard errors of the means. The different uppercase letters (A, B and C) indicate significant differences between the treatments in the same biotype. The different lowercase letters ( $a$ and $b$ ) indicate significant differences between the biotypes for a specific treatment. Both analyses were carried out after the means separation, using Fisher's least significant difference (LSD) test at $p \leq 0.05$. 
Effects of biotype (B), treatment $(\mathrm{T})$ and their interaction $(\mathrm{B} \times \mathrm{T})$ on NDVI and Canopeo values were significantly different $(p<0.001)$, except of the $\mathrm{B} \times \mathrm{T}$ effect on $\mathrm{Fv} / \mathrm{Fm}$ value $(p=0.114)$ (Figure 4$)$. The values of the maximum photochemical efficiency of PSII for 2,4-D for the Cotton-R1 biotype were significantly lower than those recorded in the biotype Cotton-R2. The plants were still photosynthetically active despite the significant reduction of their canopy cover. According to the measurements for canopy cover and photosynthetic capacity, nicosulfuron was ineffective in controlling Palmer amaranth (Figure 4 and Table 3).

\section{Cotton-S a Cotton-R1 $=$ Cotton-R2 $=$ Maize}

0.8
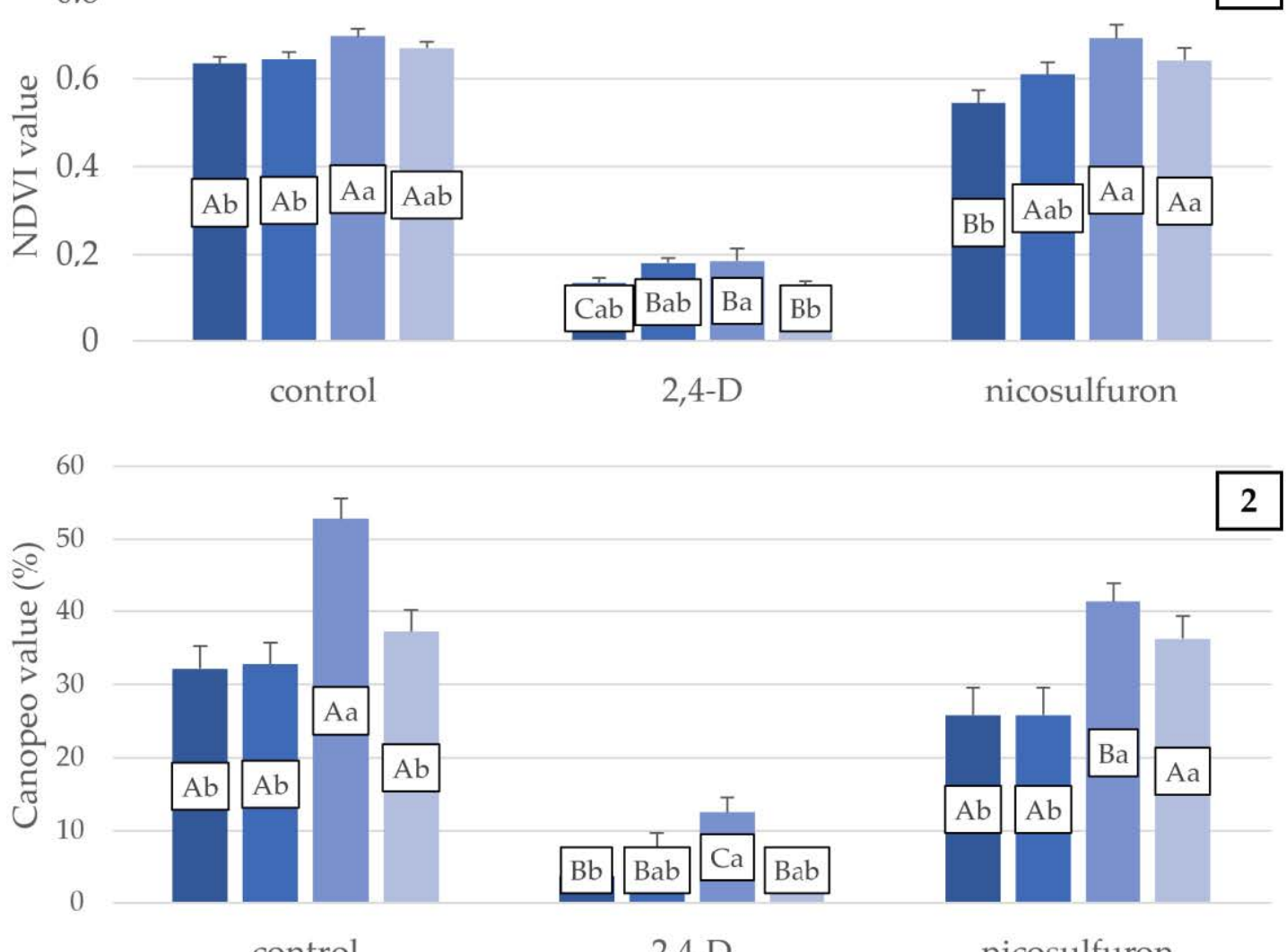

control

2,4-D

nicosulfuron

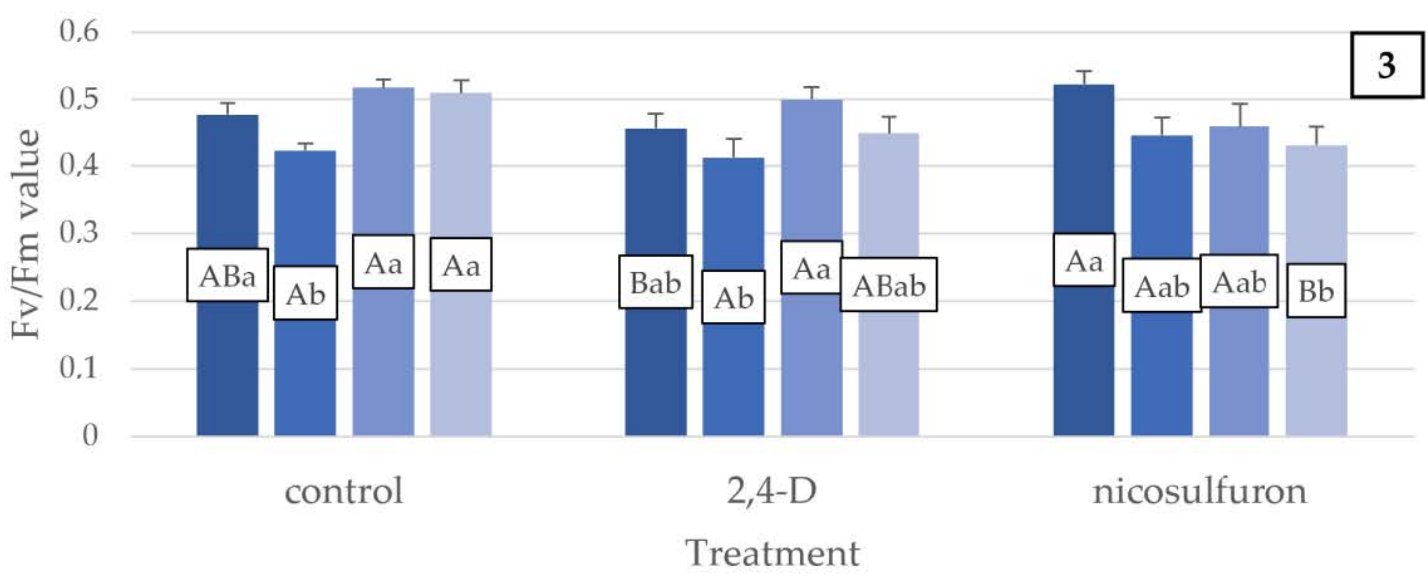

Figure 4. NDVI (1), Canopeo (2) and Fv/Fm (3) values 21 DAT for the three A. palmeri biotypes from cotton and the one from maize. Vertical bars indicate standard errors of the means. The different uppercase letters (A, B and C) indicate significant differences between the treatments in the same biotype. The different lowercase letters ( $a$ and $b)$ indicate significant differences between the biotypes for a specific treatment. Both analyses carried out after the means separation, using Fisher's least significant difference (LSD) test at $p \leq 0.05$. 
Table 3. NDVI, Canopeo, plant height, fresh weight per plant and Fv/Fm values for all the studied A. palmeri biotypes and the treatments 2,4-D and nicosulfuron compared to the untreated control for each biotype.

\begin{tabular}{ccccccc}
\hline Treatment & Biotype & NDVI & Canopeo & Plant Height & Fresh Weight & Fv/Fm \\
\hline \multirow{5}{*}{$2,4-\mathrm{D}$} & Cotton-S & $-78.7 \%$ & $-88.5 \%$ & $-50.6 \%$ & $-93.4 \%$ & $-4.2 \%$ \\
& Cotton-R1 & $-72.1 \%$ & $-80.2 \%$ & $-42.3 \%$ & $-69.5 \%$ & $-2.9 \%$ \\
& Cotton-R2 & $-73.5 \%$ & $-76.3 \%$ & $-53.4 \%$ & $-74.9 \%$ & $-3.4 \%$ \\
& Maize & $-80.6 \%$ & $-88.4 \%$ & $-45.8 \%$ & $-80.5 \%$ & $-11.8 \%$ \\
\hline \multirow{5}{*}{ Nicosulfuron } & Cotton-S & $-14.2 \%$ & $-19.8 \%$ & $-11.8 \%$ & $-63.5 \%$ & $9.4 \%$ \\
& Cotton-R1 & $-5.4 \%$ & $-21.2 \%$ & $-27.5 \%$ & $-55.5 \%$ & $5.3 \%$ \\
& Cotton-R2 & $-0.7 \%$ & $-21.8 \%$ & $-16.8 \%$ & $-11.6 \%$ & $-11.1 \%$ \\
& Maize & $-4.1 \%$ & $-2.6 \%$ & $-8.3 \%$ & $-52.6 \%$ & $-15.2 \%$ \\
\hline
\end{tabular}

The efficacy of 2,4-D and nicosulfuron is recorded in Table 3, where the values represent the reduction compared to control for all measurements and biotypes. It is observed that all biotypes are highly resistant to nicosulfuron. The fresh weight reduction significantly varied among treatments and ranged between $11.6 \%$ and $63.5 \%$ as compared to control. Nevertheless, all Palmer amaranth plants treated with nicosulfuron survived, while $3 \%, 5 \%, 10 \%$ and $3 \%$ of plants treated with 2,4-D survived in Cotton-S, Cotton-R1, Cotton-R2 and Maize biotypes, respectively. Plant height for all biotypes was negatively affected after 2,4-D application, but the plants faced significant reductions in terms of NDVI, canopy cover and fresh weight.

NDVI is a robust index that has been extensively used for measuring the response of weeds to several herbicides. This study highlights the robustness of the mobile application Canopeo for quantifying the effect of herbicides on weeds. A linear model that was used to correlate NDVI and Canopeo values $\left(Y=0.139081+0.0131745^{*} X ; n=48 ; p<0.001\right.$; rootmean-square error $($ RMSE $)=0.1001)$ indicated that the regression was positive according to the value of the correlation coefficient $(R=0.904)$ and strong given the value of the coefficient of determination $\left(R^{2}=81.836 \%\right)$. Canopeo app is suggested as an alternative or an additional tool to NDVI for the evaluation of the herbicide efficacy in small scale pot experiments. Nevertheless, the measurement of photosynthetic capacity is imperative to evaluate whether an herbicide is effective against a weed, or it just causes growth inhibition and the plant tissues recover.

\section{Discussion}

The current study is the first report of Palmer amaranth in the spring crops of Greece. Early identification and limiting spread via several pathways are considered to be critical steps in managing Palmer amaranth. Several studies have shown that Palmer amaranth seeds can be dispersed via farm equipment, such as cotton gins, contaminated seed mixes and manure, and this could probably be the case in Greece as well $[9,10]$. Furthermore, resistance present in Palmer amaranth biotypes in Greece either evolved due to monoculture of spring crops in some regions or was already present in the seed that was unintentionally introduced. In particular, our findings revealed that all the tested Palmer amaranth biotypes demonstrated resistance to the ALS inhibitor, nicosulfuron. All biotypes showed susceptibility to the synthetic auxin, 2,4-D. Farmers tend to use ALS inhibitors and synthetic auxins to manage weeds in spring arable crops; hence, Palmer amaranth populations might be pressured and evolve resistance, and escaped weeds might be observed (as mentioned above). This is a major challenge to overcome, especially in cases of field margins where Palmer amaranth is abundant, because, due to cross-pollination, herbicide-resistance genetic traits might be transferred to new populations. The near-field spray drift has been reported as a potential mechanism that rapidly selects for herbicide resistant biotypes and might lead to weed-management failures [11].

Overall, 2,4-D is a highly effective herbicide that is used in many crops for the control of Palmer amaranth. The weed has been controlled efficiently with sequential applications 
with 2,4-D in soybean, providing more than $90 \%$ control and $99 \%$ biomass reduction f14 days after late post-application [12]. At a rate of $560 \mathrm{~g}$ a.e. ha ${ }^{-1}, 2,4-\mathrm{D}$ resulted in $81 \%$ control of Palmer amaranth and $72 \%$ reduction of dry weight at 28 days after treatment targeting 5-10 cm glyphosate resistant Palmer amaranth [13]. However, among different biotypes, the susceptibility to 2,4-D varies vastly. In their research, Kumar et al. (2020) observed that the visible injury of Palmer amaranth, due to 2,4-D, ranged between 58 and $100 \%$ at 21 days after treatment in an assessment of 28 Kansas populations, indicating the evolution of resistance [14]. In double-crop soybean, 2,4-D at a rate of $561 \mathrm{~g}$ a.e. ha-1 provided only 5\% control of Palmer amaranth 8 weeks after sowing [15].

Palmer amaranth has been recently listed as a recommended invasive plant species for regulation in EPPO A2 list (2020). Arianoutsou et al. (2010) considered Palmer amaranth as a naturalized alien species of Greek flora [16]. However, our record is the first report of Palmer amaranth in agricultural areas in Greece and highlights the importance of treating A. palmeri as a weed and a threat for agricultural production. Soybean, cotton and sweet potato are some crops with slow first growth that are vulnerable to Palmer amaranth competition and suffer high yield losses. For instance, sweet potato yield has been reported to be reduced by $0.5 \%$ on average for every $1 \mathrm{~cm}$ of height of Palmer amaranth [17]. Soybean interference with Palmer amaranth has been reported to result in high yield losses if early infestation occurs 0-2 weeks after soybean emergence [18]. Proper actions should be conducted in the areas of investigation about the introduction of the weed among farmers, agricultural advisors and policy-makers. Should Palmer amaranth distribution be limited on Western Greece and Central Greece the following years, then the management would become less complicated and challenging. Weed mapping tools and new technologies, such as Decision Support Systems [19], are useful tools to track the invasiveness dynamics of Palmer amaranth and avoid the evolution of herbicide resistance by adopting strategies that focus on the long-term management of the weed. The exploitation of weed emergence and phenology prediction models are considered valuable tools to achieve early control and mitigate the impact to yields [20]. Moreover, in the present study we suggest that the measurement of photosynthetic capacity along with other parameters and indices is imperative to evaluate whether an herbicide is effective against a weed and quantify this effect.

Houston et al. (2019) suggested that, for the management of Palmer amaranth, a pre-emergence herbicide and repeated treatments with effective post-emergence herbicides are required [21]. The addition of adjuvants in the tank mixtures has been proven a very efficient option to increase herbicide efficacy against the noxious weeds Lolium rigidum, Conyza canadensis and Conyza sumatrensis [22,23] and could be also applied against Palmer amaranth along with other methods [6,7]. The management of Palmer amaranth cannot rely exclusively on chemical means, due to the emerging herbicide resistance cases and the goals of European Green Deal for 50\% reduction of chemical input by 2030. Under this context, herbicide alternatives are imperative to be included in integrated weed management programs. Sowing of a winter cover crop, such as rye (Secale cereale L.) combined with herbicides, has been reported to reduce the growth of Palmer amaranth [8,24]. Grazing is another strategy that could be adopted to reduce the weed germinable seed bank, but only in some orchards and uncultivated land [25]. Natural herbicides, such as pelargonic acid, and false seedbed technique are promising tools that have been tested under Greek conditions and could be applied for the management of Palmer amaranth [26,27].

\section{Conclusions}

In the present study, Palmer amaranth has been reported for the first time in maize, sorghum and cotton fields in Greece. This highly invasive weed species is expected to cause significant yield losses if no effective weed-management programs are adopted. A first screening of four biotypes of Palmer amaranth from two agricultural regions of Greece via NDVI, canopy cover, photochemical efficiency, plant height and fresh weight revealed that the weed has probably evolved resistance to nicosulfuron (ALS inhibitor). Herbicide 
resistance may result in herbicide failures, increase of production costs and long-term threat for the sustainability of important crops for the Greek agricultural sector, such as maize, cotton, soybean and sorghum. Further research should be conducted to evaluate several herbicides, validate the herbicide resistance cases and find alternatives for the long-term management of Palmer amaranth. On this axis, remote sensing and smart applications are useful tools to conduct rapid and robust research.

Author Contributions: Conceptualization, P.K. and I.T.; methodology, P.K., A.T., V.D. and I.T.; validation, P.K., A.T., V.D. and I.T.; formal analysis, P.K., A.T. and I.T.; investigation, P.K., A.T., V.D. and I.T.; resources, P.K., A.T. and I.T.; data curation, P.K., A.T., V.D. and I.T.; writing-original draft preparation, P.K., A.T., V.D. and I.T.; writing-review and editing, P.K., A.T., V.D. and I.T.; visualization, P.K., A.T. and I.T.; supervision, I.T.; project administration, I.T.; All authors have read and agreed to the published version of the manuscript.

Funding: This research received no external funding.

Conflicts of Interest: The authors declare no conflict of interest.

\section{References}

1. Ward, S.M.; Webster, T.M.; Steckel, L.E. Palmer amaranth (Amaranthus palmeri): A review. Weed Technol. 2013, 27, 12-27. [CrossRef]

2. Kumar, V.; Liu, R.; Boyer, G.; Stahlman, P.W. Confirmation of 2,4-D resistance and identification of multiple resistance in a Kansas Palmer amaranth (Amaranthus palmeri) population. Pest Manag. Sci. 2019, 75, 2925-2933. [CrossRef]

3. Heap, I. The International Herbicide-Resistant Weed Database. 2021. Available online: www.weedscience.org (accessed on 15 May 2021).

4. Torra, J.; Royo-Esnal, A.; Romano, Y.; Osuna, M.D.; León, R.G.; Recasens, J. Amaranthus palmeri a new invasive weed in Spain with herbicide resistant biotypes. Agronomy 2020, 10, 993. [CrossRef]

5. Milani, A.; Panozzo, S.; Farinati, S.; Iamonico, D.; Sattin, M.; Loddo, D.; Scarabel, L. Recent discovery of Amaranthus palmeri S. Watson in Italy: Characterization of ALS-resistant populations and sensitivity to alternative herbicides. Sustainability 2021, 13, 7003. [CrossRef]

6. Schwartz-Lazaro, L.M.; Norsworthy, J.K.; Scott, R.C.; Barber, L.T. Resistance of two Arkansas Palmer amaranth populations to multiple herbicide sites of action. Crop Prot. 2017, 96, 158-163. [CrossRef]

7. Webster, T.M.; Simmons, D.B.; Culpepper, A.S.; Grey, T.L.; Bridges, D.C.; Scully, B.T. Factors affecting potential for Palmer amaranth (Amaranthus palmeri) suppression by winter rye in Georgia, USA. Field Crops Res. 2016, 192, 103-109. [CrossRef]

8. Travlos, I.; Tsekoura, A.; Antonopoulos, N.; Kanatas, P.; Gazoulis, I. Novel sensor-based method (quick test) for the in-season rapid evaluation of herbicide efficacy under real field conditions in durum wheat. Weed Sci. 2021, 69, 147-160. [CrossRef]

9. Norsworthy, J.K.; Smith, K.L.; Steckel, L.E.; Koger, C.H. Weed seed contamination of cotton gin trash. Weed Technol. 2009, 23, 574-580. [CrossRef]

10. Yu, E.; Blair, S.; Hardel, M.; Chandler, M.; Thiede, D.; Cortilet, A.; Gunsolus, J.; Becker, R. Timeline of Palmer amaranth (Amaranthus palmeri) invasion and eradication in Minnesota. Weed Technol. 2021, 1-9. [CrossRef]

11. Vieira, B.C.; Luck, J.D.; Amundsen, K.L.; Werle, R.; Gaines, T.A.; Kruger, G.R. Herbicide drift exposure leads to reduced herbicide sensitivity in Amaranthus spp. Sci. Rep. 2020, 10, 2146. [CrossRef]

12. Shyam, C.; Chahal, P.; Jhala, A.; Jugulam, M. Management of glyphosate-resistant Palmer amaranth (Amaranthus palmeri) in 2,4-D-, glufosinate-, and glyphosate-resistant soybean. Weed Technol. 2021, 35, 136-143. [CrossRef]

13. Lawrence, B.H.; Bond, J.A.; Eubank, T.W.; Golden, B.R.; Cook, D.R.; Mangialardi, J.P. Evaluation of 2, 4-D-based herbicide mixtures for control of glyphosate-resistant Palmer amaranth (Amaranthus palmeri). Weed Technol. 2019, 33, 263-271. [CrossRef]

14. Kumar, V.; Liu, R.; Stahlman, P.W. Differential sensitivity of Kansas Palmer amaranth populations to multiple herbicides. Agron. J. 2020, 112, 2152-2163. [CrossRef]

15. Hay, M.M.; Shoup, D.E.; Peterson, D.E. Herbicide options for control of Palmer amaranth (Amaranthus palmeri) and common waterhemp (Amaranthus rudis) in double-crop soybean. Weed Technol. 2019, 33, 106-114. [CrossRef]

16. Arianoutsou, M.; Bazos, I.; Delipetrou, P.; Kokkoris, Y. The alien flora of Greece: Taxonomy, life traits and habitat preferences. Biol. Invasions 2010, 12, 3525-3549. [CrossRef]

17. Smith, S.C.; Jennings, K.M.; Monks, D.W.; Chaudhari, S.; Schultheis, J.R.; Reberg-Horton, C. Critical timing of Palmer amaranth (Amaranthus palmeri) removal in sweetpotato. Weed Technol. 2020, 34, 547-551. [CrossRef]

18. Korres, N.E.; Norsworthy, J.K.; Mauromoustakos, A.; Williams, M.M. Soybean density and Palmer amaranth (Amaranthus palmeri) establishment time: Effects on weed biology, crop yield, and economic returns. Weed Sci. 2020, 68, 467-475. [CrossRef]

19. Kanatas, P.; Travlos, I.S.; Gazoulis, I.; Tataridas, A.; Tsekoura, A.; Antonopoulos, N. Benefits and limitations of decision support systems (DSS) with a special emphasis on weeds. Agronomy 2020, 10, 548. [CrossRef] 
20. Reinhardt Piskackova, T.A.; Reberg-Horton, S.C.; Richardson, R.J.; Jennings, K.M.; Franca, L.; Young, B.G.; Leon, R.G. Windows of action for controlling palmer amaranth (Amaranthus palmeri) using emergence and phenology models. Weed Res. 2021, 61, 188-198. [CrossRef]

21. Houston, M.M.; Norsworthy, J.K.; Barber, T.; Brabham, C. Field evaluation of preemergence and postemergence herbicides for control of protoporphyrinogen oxidase-resistant Palmer amaranth (Amaranthus palmeri S. Watson). Weed Technol. 2019, 33, 610-615. [CrossRef]

22. Palma-Bautista, C.; Tataridas, A.; Kanatas, P.; Travlos, I.S.; Bastida, F.; Domínguez-Valenzuela, J.A.; De Prado, R. Can control of glyphosate susceptible and resistant Conyza sumatrensis populations be dependent on the herbicide formulation or adjuvants? Agronomy 2020, 10, 1599. [CrossRef]

23. Palma-Bautista, C.; Vazquez-Garcia, J.G.; Travlos, I.; Tataridas, A.; Kanatas, P.; Domínguez-Valenzuela, J.A.; De Prado, R. Effect of adjuvant on glyphosate effectiveness, retention, absorption and translocation in Lolium rigidum and Conyza canadensis. Plants 2020, 9, 297. [CrossRef] [PubMed]

24. Webster, T.M.; Scully, B.T.; Grey, T.L.; Culpepper, A.S. Winter cover crops influence Amaranthus palmeri establishment. Crop Prot. 2013, 52, 130-135. [CrossRef]

25. Leon, R.G.; Wright, D.L. Recurrent changes of weed seed bank density and diversity in crop-Livestock systems. Agron. J. 2018, 110, 1068-1078. [CrossRef]

26. Travlos, I.; Rapti, E.; Gazoulis, I.; Kanatas, P.; Tataridas, A.; Kakabouki, I.; Papastylianou, P. The herbicidal potential of different pelargonic acid products and essential oils against several important weed species. Agronomy 2020, 10, 1687. [CrossRef]

27. Kanatas, P.J.; Travlos, I.S.; Gazoulis, J.; Antonopoulos, N.; Tsekoura, A.; Tataridas, A.; Zannopoulos, S. The combined effects of false seedbed technique, post-emergence chemical control and cultivar on weed management and yield of barley in Greece. Phytoparasitica 2020, 48, 131-143. [CrossRef] 